\title{
Mirušu cilvēku personas datu aizsardzība
}

\author{
Mg. iur. Džena Andersone \\ Latvijas Universitāte, Juridiskā fakultāte, Doktora studiju programma \\ dzenaandersone@inbox.lv
}

\section{Kopsavilkums}

Raksta mērḳis ir sniegt ieskatu par mirušu cilvēku personas datu aizsardzības aspektiem. Mērḳa sasniegšanai tiek aplūkots normatīvais regulējums un īstenotā prakse saistībā ar mirušo personu datu apstrādi. Mirušo personu datu apstrādē biežāk tiek izmantotas tās tiesību normas, kas attiecas uz mirušo pacientu datu apstrādi, taču arī šāda prakse visos gadījumos nav konsekventa. Rakstā tiek analizētas Ārstniecības likuma un Pacientu tiesību likuma normas personas datu aizsardzības kontekstā. Pacientu tiesību likuma normas nav izmantojamas situācijās, kas ir ārpus medicīnas iestāžu kompetences un mirušo pacientu personas datu aizsardzības tvēruma. Tāpēc rakstā galvenā uzmanība veltìta nepieciešamībai izstrādāt atsevišķus noteikumus mirušu cilvēku personas datu apstrādei.

Atslēgvārdi: personas dati, mirušu cilvēku personas dati, pacientu dati, mirušu pacientu dati.

\section{levads}

2018. gada 25. maijā stājās spēkā 2016. gada 27. aprīḷa Eiropas Parlamenta un Padomes regula 2016/679 par fizisku personu aizsardzību attiecībā uz personas datu apstrādi un šādu datu brīvu apriti, ar ko tiek atcelta Direktīva 95/46/EK (Vispārīgā datu aizsardzības regula, turpmāk - arī Regula). Atbilstoši Vispārīgās datu aizsardzỉbas regulas preambulas 27. punktam Regula netiek piemērota mirušu cilvēku personas datiem, atstājot dalībvalstīm iespēju paredzēt atseviškus noteikumus par mirušu cilvēku personas datu apstrādi [3].

Latvijā spēkā esošajā Fizisko personu datu aizsardzības likumā [4] un jaunajā Personas datu apstrādes likumā [7], kura likumprojekts ir atbalstīts Saeimas Juridiskajā komisijā un virzîts izskatīšanai Saeimā pirmajā lasījumā, nav paredzēti kādi noteikumi mirušu cilvēku personas datu apstrādei. Taču ikdienas darbā rodas situācijas, kurās jautājums 
par mirušu cilvēku personas datu iegūšanu un izmantošanu kḷūst aktuāls. Turklāt šis jautājums pēdējos gados ticis apspriests arī plašsaziņas līdzekḷos saistībā ar internetā pieejamiem aizgājēju profiliem sociālajos tīklos. Tāpēc šì raksta mērḳis ir nedaudz plašāk aplūkot problēmas, kas saistītas ar to, ka nav regulējuma mirušu cilvēku personas datu apstrādes jomā, un sniegt priekšlikumus situācijas risināšanai.

Rakstā izmantotas šādas tiesību normu interpretācijas metodes: gramatiskā (valodnieciskā viedokḷa noskaidrošanai), sistēmiskā (sasaistes ar citām normām noskaidrošanai) un teleologiskā (jēgas un mērḳa noskaidrošanai) tiesību normu interpretācijas metode. Balstoties uz noskaidrotajām atziṇām un viedokḷiem par pētījuma objektu, izmantotā aprakstošā metode l̦auj interpretēt pētỉjuma rezultātus.

\section{Mirušu cilvēku personas datu aizsardzības prakse}

Latvijā normatīvais regulējums neparedz mirušu cilvēku personas datu aizsardzību, un arī citur pasaulē personas datu aizsardzības regulējums parasti tiek attiecināts tikai uz dzīvu cilvēku datiem. Pasaulē ir tikai dažas valstis, kuru normatīvajā regulējumā tieši un nepārprotami ir teikts, ka personas dati ir informācija gan par dzīvu, gan mirušu cilvēku.

Šādā veidā personas dati tiek definēti, piemēram, Islandes Datu aizsardzības likuma otrajā pantā [20]. Savukārt Singapūras Personas datu aizsardzības likumā jēdziens "indivīds" tiek attiecināts gan uz dzīvu, gan mirušu personu, taču viss minētais tiesību akts attiecībā uz mirušām personām netiek piemērots, izṇemot personas datu izpaušanas aizliegumu un nosacījumu, ka mirušo cilvēku personas dati tiek aizsargāti desmit gadus pēc personas nāves [18]. Savukārt Dānijas Kriminālkodeksa 264. d paragrāfā paredzēts sods (naudas sods vai brīiības atņemšana uz laiku līdz sešiem mēnešiem) par tādu attēlu vai informācijas pārsūtîšanu, kas saistīta ar citas personas, tostarp mirušas personas, privāto dzīvi [9].

Atbilstīgi Datu aizsardzības aktam Skotijā mirušu personu dati netiek pielīdzināti dzīvu personu datiem, un saskañā ar Skotijas Informācijas brīvības likumu (2002) [15] informāciju par mirušu personu ir iespējams iegūt, taču likumā nostiprināts arī izṇēmums, proti, nevienam netiek izsniegta informācija, kas satur mirušās personas veselības datus un ziṇas, kas par personu iegūtas sociālās aprūpes laikā [12]. Atbilstīgi spēkā esošajam likumam un nostiprinātajai tiesu praksei [11] ziṇas no mirušās personas slimības vēstures netiek izsniegtas arī radiniekiem, tostarp vecākiem.

Latvijā Datu valsts inspekcija rekomendācijā "Personas datu definīcija" atzīst, ka miruša cilvēka dati jāaizsargā atsevišḳos gadījumos [10]. Piemēram, situācijās, kurās informācija par mirušo vienlaikus attiecas arī uz dzīvām personām. ${ }^{1}$ Arī juristu vidū ir

${ }^{1}$ Datu valsts inspekcija norāda: "Informācija par mirušām personām var attiekties arī uz dzīvām personām. Piemēram, informācija par to, ka mirusī Anna slimoja ar hemofiliju, norāda, ka viṇas dēls Jānis arī slimo ar šo pašu slimību, jo tā ir saistīta ar gēnu, kas atrodas X hromosomā. Tādējādi gadījumos, kad var uzskatīt, ka informācija par mirušām personām vienlaikus attiecas arī uz dzīvām personām, tā ir uzskatāma par personas datiem, uz ko attiecas Datu aizsardzības likuma noteikumi, un mirušas personas dati netieši bauda personas datu aizsardzības noteikumos paredzēto aizsardzību." 
sastopams viedoklis, ka mirušas personas dati netieši bauda personas datu aizsardzību. Tā, piemēram, E. Eglīte, analizējot personas datu apstrādes tiesiskos aspektus, norāda, ka gadījumos, ja informācija par mirušām personām vienlaikus attiecas arī uz dzīvām personām, tā jāuzskata par personas datiem, uz ko attiecināmi Fizisko personu datu aizsardzības likumā ietvertie datu apstrādes nosacījumi [14, 17].

Tādējādi mirušo personu datu aizsardzības nepieciešamība tiek saistīta vienīgi ar pienākumu vienlaikus aizsargāt kādas dzīvas personas datus. Taču mirušās personas dati paši par sevi paliek bez šādas aizsardzības. Šajā jomā nav konkrēta regulējuma, tāpēc prakse rada savus noteikumus situācijas risināšanai. Publiski pieejamā informācija par lielāko sociālo tīklu politiku šajā jautājumā liecina, ka ārvalstu portāli, piemēram, www.facebook.com (Facebook), piedāvā vairākas opcijas - gan profila dzēšanu pēc tuvinieku lūguma (uzrādot miršanas apliecību), gan piemiṇas vietnes vai virtuālā memoriāla izveidi, gan arī vēl dzīves laikā izmantojamu pakalpojumu - attiecīga rīkojuma sagatavošanu, kā portālam rīkoties ar personas sociālo profilu pēc nāves, kas līdzvērtīgi testamentam tiek izpildìts pēc miršanas apliecības uzrādīšanas [22].

Savukārt Latvijas sociālā vietne Draugiem.lv personas nāves gadījumā piedāvā tikai vienu opciju - dzēst personas profilu. Mirušo lietotāju profili tiek dzēsti pēc pirmās pakāpes tuvinieku lūguma. Uzrādīt miršanas apliecības kopiju tiek prasīts tikai atsevišķos gadījumos, piemēram, ja nav pirmās pakāpes radinieku vai ja ir pamatotas aizdomas, ka tuvinieku viedokḷi par profila dzēšanu varētu atšḳirties. Portāls neapkopo precīzu statistiku par mirušo personu profilu dzēšanu, bet pēc vispārīgām aplēsēm nedēḷā tiek dzēsti aptuveni $5-10$ profili, t. sk. ne tikai mirušu lietotāju, bet arī viltus profili. ${ }^{2}$ Draugiem.lv pārstāvis Jānis Palkavnieks uzsver, ka mirušo personu tuviniekiem netiek izpaustas attiecīgā profila paroles, lai šādā veidā neradītu piekḷuvi konfidenciālai informācijai, proti, vēstuḷu saturam. Vienīgā iespēja, kas tiekot piedāvāta radiniekiem pirms profila dzēšanas, ir mirušās personas publicēto fotogrāfiju lejupielāde [13].

No šeit minētā secināms, ka vienotu noteikumu rīcībai ar mirušu cilvēku personas datiem nav, tomēr sabiedrība šādos gadījumos rīkojas atbilstīgi saviem morāli ētiskajiem priekšstatiem par to, ko drīkst un ko ne, cenšoties izturēties ar pietāti pret aizgājēju datiem.

\section{Mirušu pacientu personas datu aizsardzības teorētiskie jautājumi}

No Datu valsts inspekcijas rekomendācijas izriet, ka ar mirušas personas datiem galvenokārt tiek saprasti miruša pacienta dati un ar pacienta nāvi nebeidzas medicīniskā personāla pienākums glabāt profesionālos noslēpumus par personu.

Profesionālos noslēpumus medicīnā parasti apzīmē ar terminu "ārsta noslēpums", un ar to saprot visu informāciju, kas fiksēta pacienta medicīniskajā dokumentācijā. Pienākums glabāt slepenībā šìs ziṇas ir saistošs ne tikai galvenajām ārstniecības

2 Informācija no portāla Draugiem.lv 2017. gada 14. februāra elektroniskās vēstules šĩ raksta autorei. 
personām - ārstiem -, bet arī visam medicīnas iestādes personālam, tostarp atbalsta un administratīvajiem darbiniekiem, - visiem, kam tiešā vai netiešã veidā ir pieeja pacientu medicīniskajai dokumentācijai.

Datu valsts inspekcijas rekomendācija šajā jautājumā faktiski sakrīt ar Latvijas ārstu ētikas kodeksa ceturtajā punktā noteikto, ka ārsts tur slepenībā ziṇas par pacientu arī pēc pacienta nāves [17].

Analogisks ārsta noslēpuma glabāšanas pienākums paredzēts arī Austrālijas Mediḳu asociācijas vadlīnijās - aizsargāt miruša pacienta medicīnisko ziṇu konfidencialitāti ir ārsta ētisks un tiesisks pienākums. Šādas ziṇas ir izpaužamas tikai un vienīgi likumā paredzētos gadījumos [16]. Tas ir gan Apvienotās Karalistes Centrālās medicīnas padomes vadlīnijās - "mediḳu konfidencialitātes pienākums pēc pacienta nāves iestāšanās turpinās" [21], gan arī citu pasaules valstu medicīnas ètikas kodeksos un priekšrakstos.

Tādējādi var secināt, ka attiecībā uz miruša pacienta medicīniskiem datiem darbojas īpašs normatīvais regulējums. Kā jau iepriekš tika minēts, šāds speciāls tiesiskais regulējums, piemēram, Skotijā iekḷauts Skotijas Informācijas brīvības likumā (2002), savukārt Latvijā tas iestrādāts Pacientu tiesību likumā [6].

Atbilstoši Pacientu tiesību likuma 10. panta trešajai dal̦ai arī mirušu pacientu dati tiek aizsargāti. Savukārt šã paša panta ceturtajā dạ̦ā izsmel̦oši uzskaitīti izṇēmuma gadījumi, kuros informāciju par pacientu pēc viṇa nāves drīkst izpaust konkrētam personu lokam, ${ }^{3}$ proti:

- ja informācijas sniegšana var ietekmēt minēto personu dzīìibu vai veselību vai atvieglot veselības aprūpes pakalpojumu sniegšanu tām;

- ja informācija ir saistīta ar pacienta nāves cēloni vai ārstniecību laikā pirms viṇa nāves.

Pacientu tiesību likuma 10. panta ceturtās daḷas 1. punktā minētie gadïjumi, saprotams, attiecas uz situācijām, kad mirušā tuviniekiem attiecīgās ziṇas nepieciešamas sava veselības stāvokḷa nodrošināšanai, piemēram, dažādu iedzimtu slimību, genētiskas pārmantojamības u. tml. gadỉjumos, kuros precīza informācija par pārmantojamām genētiskām slimībām var būtiski palīdzēt diagnostikas un ārstēšanas procesā.

Taču minētās normas otrajā punktā formulējums nav gluži skaidrs. No normas sākuma daḷas ("informācija ir saistīta ar pacienta nāves cēloni") nepārprotami izriet mirušã radinieku tiesības uzzināt nāves cēloni, taču atklāts paliek jautājums, cik plašu informāciju šìs personas varētu saṇemt, jo, iespējams, personas slimības vēstures lielākā daḷa vai visa dokumentācija par konkrētās personas pēdējo stacionēšanas reizi varētu būt saistīta ar tās nāves cēloni.

3 Atbilstoši Pacientu tiesību likuma 7. panta pirmajai daḷai minēto personu lokā ir pacienta laulātais, bet, ja tā nav, - pilngadīgi un rīcībspējīgi tuvākie radinieki šādā secībā: pacienta bērni, pacienta vecāki, pacienta brāḷi vai māsas, pacienta vecvecāki un pacienta mazbērni. 
Savukārt normas otrajā dạ̄ā aiz vārda "vai" ("ārstniecība laikā pirms viṇa nāves") neskaidrības rada vārda "pirms" tvērums, proti, par kādu laikposmu (nedēḷām, mēnešiem vai gadiem) varētu tikt pieprasīta un saṇemta informācija par konkrēto mirušo personu. Tāpat ne mazāk svarīgs ir jautājums par pašu informācijas saturu, piemēram, vai tajā jāietver arī ziñas par lietotajiem medikamentiem, personas atkarībām u. c.

Analizētās normas otrajā punktā noteikts precīzs formulējums - "informācija saistīta ar ārstniecību". Tātad, lai labāk saprastu šo regulējumu, vispirms jānoskaidro jēdziena "ārstniecība" saturs. Saskaṇā ar Latvijā spēkā esošo Ārstniecības likumu "ārstniecība" tiek definēta kā "profesionāla un individuāla slimību profilakse, diagnostika un ārstēšana, mediciniskā rehabilitācija un pacientu aprūpe” [2].

Ar slimību profilaksi saprot visu darbïbu kompleksu, kas vērsts uz to, lai persona nesaslimtu. Diagnostika ir process, kurā tiek noteikta pacienta diagnoze un veselïbas stāvoklis, izmantojot dažādas medicinnā pien̦emtas metodes. Ārstēšana ir viss pasākumu kopums, kas tiek veikts saslimušās personas atveseḷošanai un patologiiska stāvokḷa novēršanai, tostarp medikamentozā terapija un operatīvā iejaukšanās. Turklāt ārstēšana var norisināties kā ambulatori, tā arī stacionārā.

Savukārt jēdzieni "medicīniskā rehabilitācija" un "pacientu aprūpe" ir definēti Ārstniecības likumā. Ši likuma pirmā panta 14. punktā noteikts, ka medicīniskā rehabilitācija ir atsevišḳ "medicīnas nozare, kas nodarbojas ar cilvēka fiziskā, psiholog̣iskā, sociālā, aroda un izglìtības potenciāla attīstī̌̌anu vai atgūšanu atbilstoši viņa fiziolog̣iskajiem vai anatomiskajiem ierobežojumiem, vai - stabilu veselības traucējumu gadijumā - ar pacienta dzīves pielāgošanu videi un sabiedrībai [..]”. Tā paša panta 12. punktā pacientu aprūpe tiek skaidrota kā "veselības aprūpes sastāvdaḷa, kas ir tieši vai netieši saistīta ar sabiedrības, ğimenes vai personas veselības uzturēšanu, veicināšanu, aizsardzību un atgūšanu [..]".

Minētās definīcijas un jēdzienu skaidrojumi iezīmē ārkārtīgi plašu jautājumu loku, kas Pacientu tiesību likuma 10. panta ceturtās dalıas otrajā punktā ir ḷoti lakoniski formulēts - "informācija saistīta ar ārstniecību". Taču, palūkojoties uz visu jautājumu kopumu, kas tiek aptverts ar šo īso formulējumu, var secināt, ka iegūstamo datu apjoms ir loti liels, kas turklāt nav pat konkrēti ierobežots laikā.

Datu apjoma labākai uzskatāmībai tiks modelēta situācija, par piemēru izmantojot kādu reālu prakses gadījumu saistībā ar vienu no jēdziena "ārstniecība" komponentiem, proti, diagnostiku.

Diagnostikas gaitā iegūstamā informācija var būt arī nesaistīta ar personas nāves cēloni, taču tā noteikti būs fiksēta medicīniskajos dokumentos. Piemēram, persona tiek stacionēta sakarā ar smadzen,u išēmisko lēkmi, stacionārā mirst, autopsijā konstatētais nāves cēlonis ir cerebrālās išēmijas izraisîts artērijas pilnīgs nosprostojums. Taču, iestājoties stacionārā, pacientam tiek n,emtas asinis laboratoriskiem izmeklējumiem, kuros konstatēts, ka papildu citām pamata slimībām persona bijusi arī inficēta ar cilvēka imūndeficìta vīrusu (HIV). HIV infekcija šajā gadījumā nav nāves cēlonis, taču ziṇas par to iekḷautas pacienta medicīniskajā kartē, tostarp ārsta gatavotajā slimības izrakstā - epikrīzē. Šādas 
informācijas izsniegšana mirušā tuviniekiem var radīt visai neparedzamas sekas. Ievērojot, ka visbiežāk medicīniskie dati par mirušu cilvēku tiek pieprasīti saistībā ar dažādām tiesvedībām, neapšaubāmi, šādas konfidenciālas ziṇas var kḷūt zināmas arī plašākam personu lokam, piemēram, otrai tiesvedībā iesaistītajai pusei.

Neatrisināts paliek arī jautājums par analizējamā pantā paredzēto personu loku, kam likumdevējs piešḳīris tiesības saṇemt informāciju par mirušo pacientu. Pacientu tiesību likumā ir noteiktas ne tikai personas, kuras tiesīgas saṇemt ziṇas par mirušo, bet imperatīvi arī secība, kā tas darāms. Pirmā un galvenā persona šajā rindā ir pacienta laulātais. Pēc tam seko atruna - "ja tāda nav", tad - bērni, vecāki, brāḷi, māsas utt. Taču šis formulējums būtiski ierobežo pacienta pilngadīgo bērnu tiesības uzzināt sava tēva vai mātes nāves cēloni vai ārstniecību pirms nāves arī gadỉjumā, ja mirušo pacientu pārdzīvojušais laulātais (kurš turklāt var arī nebūt pacienta bērnu vecāks) to nemaz nevēlas.

Situācijās, kurās kādam no mirušā tuviniekiem ir aizdomas par radinieka īsto nāves cēloni ${ }^{4}$ vai ar to saistītajām medicīniskajām manipulācijām un ārstniecības kvalitāti kopumā, kas varēja izraisīt personas nāvi, nedrīkstētu šim tuviniekam liegt tiesības aktīivi iesaistīties procedūrā (ja laulātais vai kāds cits radinieks, kam atbilstoši likumā sniegtajam formulējumam ir priekšroka, to nedara), kas saistìta ar atbilstošu ziṇu iegūšanu un nodošanu attiecīgām tiesībsargājošām iestādēm izmeklēšanas darbību veikšanai, ekspertīzes pieprasišanai $u$. tml.

\section{Mirušu pacientu personas datu aizsardzība praksē}

Par iepriekš analizētās normas nepietiekamu skaidrību liecina arī prakse, kura parāda, ka Pacientu tiesību likuma normu interpretācija ir atškirīīga un piemērošana nekonsekventa. Piemēram, kāda persona tiesvedības nolūkos vērsās ar iesniegumu Rīgas Psihiatrijas un narkologijas centrā, lai iegūtu ziņas par savu mirušo tēvu, proti, vai vin̦š sirdzis ar garīgām slimībām, vai bijis klīnikas uzskaitē, vai lietojis psihotropos medikamentus. Šì informācija personai bija nepieciešama aizdomu dēḷ, ka tēvam bijuši psihiskās veselỉbas traucējumi, kuri viṇam, iespējams, pilnībā nav l̦āvuši saprast savu darbību nozīmi, vadìt tās un apzināties savas rīcības sekas, ieḳīājot vairākus ğimenes īpašumus. Pēc šìs personas nāves mantiniekiem, tostarp dēlam, radās pienākums pret kreditoriem tēva uzkrāto parādu dēḷ. Ar līdzīgu pieprasījumu mirušã dēls vērsās arī rehabilitācijas centrā "Jaunḳemeri”, Paula Stradiṇa Klīniskajā universitātes slimnīcā un vēl dažās medicīnas iestādēs, lai noskaidrotu apstākḷus un iemeslus, kāpēc viṇa tēvs ilgstoši bija ārstējies un uzturējies šajos stacionāros.

4 Līdz 2005. gada 15. aprīlim Latvijā bija spēkā likums "Par civilstāvokḷa aktiem”, kurā bija noteikts, ka nāves cēloni norāda ne tikai miršanas registrā, bet arī miršanas apliecībā. Kopš likums zaudēja spēku un šajā jomā tika pieṇemti jauni normatīvie akti, nāves cēloni miršanas apliecībā nenorāda, un tas apgrūtina tuviniekiem šādas informācijas ieguvi. 
Gan Rīgas Psihiatrijas un narkologijas centrs, gan rehabilitācijas centrs "Jaunḳemeri”, gan arī Paula Stradiṇa Klīniskā universitātes slimnīca, atsaucoties uz Pacientu tiesību likuma 10. panta ceturto daḷu, atteicās sniegt mirušās personas datus (medicīnisko dokumentu kopijas) dēlam, kam tie bija vajadzīgi tiesvedībai. Atteikumā tika norādīts, ka iesniegumā minētais datu apstrādes mērḳis neatbilst nevienam no likumā paredzētajiem informācijas sniegšanas tiesiskajiem pamatiem. Rīgas Psihiatrijas un narkologijas centra un Paula Stradiṇa Klīniskās universitātes slimnīcas atbildēs turklāt tika norādīts, ka informāciju var izprasìt ar tiesas starpniecību.

Savukārt Nacionālais veselības dienests šajā situācijā nepiemēroja Pacientu tiesību likumu un atškirīgi interpretēja normatīvos aktus, proti, Nacionālais veselības dienests savā atbildes vēstulē atsaucās uz Datu valsts inspekcijas rekomendācijā "Personas datu definīcija" minēto par mirušu personu datu aizsardzību atsevišḳos gadījumos, kā arī uz Fizisko personu datu aizsardzības likuma 2. panta 8. punktu (tādējādi atzīstot pieprasìto informāciju par sensitīviem datiem) un Informācijas atklātības likuma [5] 5. panta otrās daḷas 4. punktu (par ierobežotas pieejamības informāciju uzskatāma informācija par fiziskās personas privāto dzīvi).

Nacionālais veselïbas dienests veica izvērstu sensitīvo datu pieprasījuma pamatojuma analīzi, balstoties uz atziṇu, ka trešajām personām šāda informācija tiek nodota tikai gadījumā, ja informācijas pieprasītājs ir pierādījis savas tiesības iegūt šo informāciju un šì datu apstrāde atbilst kādam no Datu aizsardzỉbas likumā noteiktajiem tiesiskajiem nosacỉjumiem. Nacionālais veselïbas dienests uzskatīja, ka datu pieprasītāja mērḳis - vēršanās tiesā ar pieteikumu par pēcnāves ekspertīzes nozīmēšanu mirušajam tēvam - atbilst Datu aizsardzības likuma 11. panta 6. punktā ${ }^{-5}$ paredzētajam sensitīvu datu apstrādes izṇēmuma gadījumam un Datu aizsardzības likuma 13. panta otrajā dạ̦ā ${ }^{6}$ paredzētajai kārtībai. Nacionālais veselības dienests atzina personas tiesības uz mirušās personas sensitīvo datu saṇemšanu un izmantošanu tiesvedības nolūkā. Iznākumā Nacionālais veselības dienests mirušās personas dēlam izsniedza informācijas apkopojumu par visiem sniegtajiem ambulatorajiem un stacionārajiem veselības aprūpes pakalpojumiem kopš 2003. gada 19. jūlija, ${ }^{7}$ kas ietvēra visas šajā laikposmā līdz pat nāves brīdim reǵistrētās aprūpes epizodes un hospitalizācijas gadỉjumus ārstniecības iestādēs (tostarp informāciju par iestādes konkrēto ārstējošo ārstu, pie kura pacients vērsies, pilnu giimenes ārsta kontaktinformāciju, diagnozēm u. c. ziṇas).

${ }^{5}$ Sensitīvo personas datu apstrāde ir aizliegta, izṇemot gadījumu, kad apstrāde attiecas uz tādiem personas datiem, kuri ir nepieciešami fiziskās vai juridiskās personas tiesību vai likumisko interešu aizsardzībai tiesā.

${ }^{6}$ Personas datus var izpaust, pamatojoties uz rakstveida iesniegumu vai vienošanos, norādot datu izmantošanas mērḳi, ja likumā nav noteikts citādi. Personas datu pieprasījumā norādāma informācija, kas ḷauj identificēt datu pieprasītāju un datu subjektu, kā arī pieprasāmo personas datu apjoms.

7 Datums, kad Latvijā veselības aprūpes nozarē tika sākta vienota fizisku personu datu apstrādes sistēmas darbība. 
Informācijas apkopojumā bija ietvertas arī ziṇas par personas nāves faktu un cēloni. Nacionālā veselības dienesta atbildē papildus bija ietverta arī informācija par visiem aptiekā izsniegtajiem medikamentiem, par kuriem attiecīgie farmaceiti veikuši datu ievadi vadības informācijas sistēmā. Informatīvajā apkopojumā bija iekḷauti tikai dati, kas netiek reǵistrēti vienotajā regiistrā, proti, ziṇas par neatliekamās medicīniskās palīdzības sniegtiem pakalpojumiem (izsaukumiem), pacientam nozìmēto terapiju un medicīnisko dokumentāciju.

Citas ārstniecības iestādes, piemēram, Madonas slimnīca un Rìgas Austrumu klīniskā universitātes slimnīca, mirušās personas dēlam izsniedza visas to rīcībā esošās medicīniskās dokumentācijas kopijas par tēva ārstēšanos slimnīcā, saṇemot par to attiecīgu samaksu, kas noteikta slimnīcu cenrāžos, par medicīnisko karšu kopiju izgatavošanu, noformēšanu un iesiešanu.

Vērtējot konkrēto gadījumu, konstatējams, ka prakse mirušu personu medicīnisko datu izsniegšanas jautājumos Latvijā ir loti atšḳirīga un nav vērojama vienota pieeja normatīvā regulējuma interpretācijā.

Šobrīd vēl spēkā esošā Fizisko personu datu aizsardzības likuma 11. pantā uzskaitītie sensitīvo datu (tostarp medicīnisko datu) apstrādes izṇēmuma gadījumi ir daudz plašāki nekā Pacientu tiesību likuma 10. pantā paredzētie, un ir saskatāma abu šo normu kolīzija.

Ievērojot, ka Fizisko personu datu aizsardzības likums zaudē spēku līdz ar Vispārīgās datu aizsardzības regulas spēkā stāšanos, svarīgi ir precizēt Pacientu tiesību likumu dạ̦ā, kas attiecas uz pacientu datu aizsardzības jautājumiem (likuma 10. pantu), lai panāktu tā atbilstību Regulas prasībām par īpašu kategoriju personas datu apstrādi.

Regulas 9. pantā ir paredzēti nosacījumi ìpašu kategoriju personas datu apstrādei, tie ir dati, kas atklāj rases vai etnisko piederību, politiskos uzskatus, religisko vai filozofisko pārliecību, dalību arodbiedrībās, seksuālo orientāciju, ziṇas par dzimumdzìvi, kā arī genētiskie, biometriskie un veselības dati.

Šã panta otrajā daḷā ir paredzēta virkne izṇēmumu apstrādes aizliegumam, starp kuriem ir jau ierastie (Fizisko personu datu aizsardzības likumā iekḷautie nosacījumi) kritēriji, kā arī noteikti jauni, piemēram, gadījumi, kad "apstrāde ir vajadzīga profilaktiskās vai arodmedicīnas nolūkos, darbinieka darbspējas novērtēšanai, mediciniskas diagnozes, veselības vai sociālās aprūpes, vai ārstēšanas, vai veselības, vai sociālās aprūpes sistēmu un pakalpojumu pārvaldības nodrošināšanas nolūkos". No vienas puses, šis nosacījums ir tuvs Fizisko personu datu aizsardzības likuma 11. panta 5. punktā minētajam izṇēmumam - "personas datu apstrāde ir nepieciešama ārstniecības vajadzībām, veselības aprūpes pakalpojumu sniegšanai vai to administrēšanai un zāḷu un medicīnisko ierīču izplatišanai vai to administrēšanai", taču Regula konkrētajā gadỉjumā paredz svarīgu papildu nosacỉjumu, proti, medicīniskās diagnozes, veselības, sociālās aprūpes, ārstēšanas u. tml. nolūkos personas datus var apstrādāt tikai tajā gadijumā, ja šos datus apstrādā profesionālis, uz kuru attiecas dienesta noslēpuma ievērošanas pienākums, vai dati tiek apstrādāti šāda profesionāḷa atbildībā, vai datus apstrādā cita persona, uz kuru arī attiecas pienākums ievērot dienesta noslēpumu. 
Tādējādi Regula netiešā veidā uzliek dalībvalstīm pienākumu pieṇemt noteikumus par dienesta noslēpumu, kas attiektos tieši uz veselības aprūpes un ārstniecības jomu. Kā jau iepriekš norādìts, medicīnā ar terminu "ārsta noslēpums" apzīmē visu informāciju, kas fiksēta pacienta medicīniskajā dokumentācijā, un pienākums glabāt slepenībā šo informāciju ir saistošs visam medicīnas iestādes personālam. Tomēr, lai panāktu konsekventu un vienādu gan dzīvu, gan mirušu personu veselības, medicīniskās un sociālās aprūpes datu apstrādi, nepieciešams precizēt Pacientu tiesību likumu, vienādojot terminoloǵiju atbilstīgi Regulā izmantotajiem jēdzieniem un likuma 10. panta $5^{2}$. dạ̣a paredzot, ka veselības informācijas sistēmā uzkrāto informāciju par pacientiem apstrādā tikai tās personas, uz kurām attiecas dienesta noslēpuma ievērošanas pienākums. Šajā gadījumā dienesta noslēpuma saturam Regulas izpratnē attiecībā uz personas datu apstrādi jābūt vienādam neatkarīgi no Pacientu tiesību likuma 10. panta $5^{2}$. daḷā uzskaitīto subjektu ${ }^{8}$ darba pienākumu un funkciju specifikas.

Minētais dạ̣ēji sasaucas arī ar Regulā noteiktajām dalībvalstu tiesībām saglabāt vai ieviest papildu nosacījumus attiecībā uz genētisko datu, biometrisko datu vai veselības datu apstrādi. Ja normatīvie akti netiks savstarpēji saskaņoti vai minētie datu apstrādes jautājumi tiks atstāti bez atbilstīga regulējuma vispār, tad līdz ar Regulas spēkā stāšanos un Fizisko personu datu aizsardzības likuma spēka zaudēšanu Pacientu tiesību likuma un Ārstniecības likuma normas nebūs pilnībā atbilstošas personas datu apstrādes principiem un nespēs nodrošināt prasības izpildi (ka veselības un citus ippašu kategoriju personas datus apstrādā tikai tās personas, kuras ir pakḷautas dienesta noslēpuma ievērošanas pienākumam).

\section{Mirušu cilvēku personas datu aizsardzības termiņi}

Vērtējot mirušu cilvēku personu datu aizsardzības nepieciešamību, par nozīmīgāko kritēriju ir atzīstams laiks, kas pagājis pēc cilvēka nāves.

Nevar piekrist nostādnei, ka mirušu personu dati pārstāj baudìt tiesisko aizsardzību ar brīdi, kad cilvēks miris. Šāda pieeja nebūtu atbilstoša ne no juridiskā, ne morāli ètiskā viedokḷa. Arī gadỉjumos, ja aizgājējam nav neviena tuvinieka, ja teorētiski mirušās personas dati tāpēc nevarētu tikt attiecināti ne uz vienu dzīvu personu, tomēr nebūtu piel̦aujama visu noteikumu par mirušā cilvēka datu apstrādi nekavējoša atcelšana. Ievērojot, ka jautājumu par mirušo personu datu apstrādi Regula atstāj nacionālo valstu ziṇā, Latvijā nepieciešams izstrādāt noteikumus mirušu cilvēku personas datu apstrādei, iespējams, papildinot jauno Personu datu apstrādes likumu, kura spēkā stāšanās bija plānota vienlaikus ar Regulu - 2018. gada 25. maijā.

8 Ārstniecības personas un ārstniecības atbalsta personas, farmaceiti un farmaceitu asistenti, Nacionālais veselības dienests, Veselïbas inspekcija, Valsts sociālās apdrošināšanas ağentūra, Valsts darba inspekcija, Veselības un darbspēju ekspertīzes ārstu valsts komisija. 
Kā iepriekš minēts, Singapūrā mirušu cilvēku personas dati tiek aizsargāti desmit gadus pēc personas nāves. Šãda laikposma izvēle nav pietiekami pamatota, un, kā norāda Singapūras Nacionālās Universitātes profesors Saimons Čestermans (Simon Chesterman), desmit gadu termiṇa noteikšana ir vairāk kompromisa lēmums starp tiem likumdevēja varas pārstāvjiem, kuri vēlējās likumā noteikt divdesmit gadu termiṇu mirušu personu datu aizsardzībai, un tiem, kuri principiāli iebilda pret jebkāda termiṇa iekḷaušanu likumā [8]. S. Čestermans izsaka pien̦ēmumu, ka priekšlikuma ideja par mirušu personu datu aizsardzības termiṇa noteikšanu likumā varētu nākt no Kanādas normatīvā regulējuma, atbilstoši kuram informācijas atklāšana bez personas piekrišanas ir aț̣auta pēc divdesmit gadiem pēc tās personas nāves, par kuru informācija ir pieejama [19].

Laikposms, kurā mirušu personu datiem varētu piemērot konfidencialitātes režīmu līdzīgi kā dzīvu cilvēku datiem, Latvijā būtu nosakāms pēc analog̣ijas ar Arhīvu likumā [1] noteiktajiem arhīva dokumentu pieejamības un izmantošanas ierobežojumiem. Arhīvu likuma 8. panta otrās daḷas 4. punktā noteikts, ka

"pieejamība tiek ierobežota dokumentiem, kuri satur sensitīvus personas datus vai citu
informāciju par personas privāto dzīvi (tai skaitā informāciju par personas adopciju
un notariālas darbības apliecinošu informāciju), ja tajos esošo personas datu vai infor-
mācijas izmantošana būtiski var aizskart personas privāto dzīvi. Ja citos likumos nav
paredzēti ierobežojumi, šādu dokumentu pieejamība tiek ierobežota uz 30 gadiem no
tās personas nāves, uz kuru dokuments attiecas. Ja personas nāves datumu nav iespē-
jams noteikt, pieejamība tiek ierobežota uz 110 gadiem pēc tās personas dzimšanas, uz
kuru dokuments attiecas. Ja nav iespējams konstatēt ne personas nāves, ne dzimšanas
datumu, dokumenta pieejamība tiek ierobežota uz 75 gadiem pēc dokumenta radišanas".

Šāda termiṇa noteikšana mirušu cilvēku personas datu aizsardzībai būtu pietiekami pamatota, un šāda likumā paredzētu termiṇu savstarpēja atbilstība veicinātu arī vienotu izpratni un normu piemērošanu attiecỉbā uz mirušu personu datiem un dokumentiem.

\section{Secinājumi un priekšlikumi}

1. Latvijā nav izstrādāts normatīvais regulējums mirušu cilvēku personas datu apstrādei. Nepieciešamība aizsargāt mirušu cilvēku personas datus tiek saistīta tikai ar pienākumu vienlaikus aizsargāt kādas dzīvas personas datus.

2. Mirušu cilvēku personas datu apstrāde praksē ir nekonsekventa, un cilvēki šādās situācijās cenšas rīkoties atbilstīgi saviem morāli ētiskajiem priekšstatiem.

3. Ar mirušas personas datiem biežāk tiek saprasti tieši miruša pacienta, nevis mirušas personas dati. Attiecībā uz miruša pacienta medicīniskiem datiem darbojas īpašs normatīvs regulējums, un Latvijā tas ir Pacientu tiesību likums. Atšḳirībā no mirušu pacientu medicīniskajiem datiem mirušu cilvēku personas datu aizsardzība normatīvajos aktos nav paredzēta.

4. Pacientu tiesību likums būtu precizējams atbilstoši Vispārīgās datu aizsardzības regulas terminolog̣ijai un datu apstrādes pamatnostādnēm. 
5. Latvijā nepieciešams izstrādāt noteikumus mirušu cilvēku personas datu apstrādei, un mirušu cilvēku personas datu konfidencialitātes režīms būtu nosakāms pēc analogiijas ar Arhīvu likumā noteiktajiem arhīva dokumentu pieejamības un izmantošanas ierobežojumu laika terminiem.

\section{Personal Data of Deceased Persons}

\section{Abstract}

The aim of the article is to provide an insight into the personal data protection aspects of the deceased's data. For achieving this goal, the article presents the existing regulatory framework and practice in relation to the processing of personal data of deceased persons. Such processing is more often based on provisions of the law relating specifically to the processing of deceased patients, but this practice is not consistent in all cases. The provisions of the Patients' Rights Law cannot be used in situations beyond the competence of medical institutions and scope of personal data protection of deceased patients. Therefore, the article focuses on the need to develop separate rules for the processing of personal data of deceased persons.

Keywords: personal data, personal data of deceased persons, patient data, data of deceased patients.

\section{Avoti un literatūra}

\section{Tiesību akti}

1. Arhīvu likums: Latvijas Republikas likums. Latvijas Vēstnesis. 35(4227), 03.03.2010. Iegūts no: https://likumi.lv/doc.php?id=205971 [sk. 31.03.2018.].

2. Ārstniecības likums: Latvijas Republikas likums. Latvijas Vēstnesis. 167/168(882/883), 01.07.1997. Iegūts no: https://likumi.lv/doc.php?id=44108 [sk. 31.03.2018.].

3. Eiropas Parlamenta un Padomes 2016. gada 27. aprīla regula 2016/679 par fizisku personu aizsardzību attiecībā uz personas datu apstrādi un šãdu datu brīvu apriti un ar ko atceḷ Direktīvu 95/46/EK (Vispārīgā datu aizsardzības regula). Eiropas Savienības Oficiālais Vèstnesis. L 119, 04.05.2016.

4. Fizisko personu datu aizsardzības likums: Latvijas Republikas likums. Latvijas Vēstnesis. 123/124(2034/2035), 06.04.2000. Iegūts no: https://likumi.lv/doc.php?id=4042 [sk. 31.03.2018.].

5. Informācijas atklātības likums: Latvijas Republikas likums. Latvijas Vèstnesis. 334/335 (1395/1396), 06.11.1998. Iegūts no: https://likumi.lv/doc.php?id=50601 [sk. 31.03.2018.].

6. Pacientu tiesību likums: Latvijas Republikas likums. Latvijas Vēstnesis. 205(4191), 30.12.2009. Iegūts no: https://likumi.lv/doc.php?id=203008 [sk. 31.03.2018.].

7. Personas datu apstrādes likums: likumprojekts (1182/Lp12), 14.03.2018. Latvijas Republikas Saeima. Iegūts no: http://titania.saeima.lv/LIVS12/saeimalivs12.nsf/0/C74799DB57161C61C2 25825000483C5F?OpenDocument [sk. 31.03.2018.]. 


\section{Literatūra}

8. Chesterman, S. After privacy: The rise of Facebook, the fall of Wikileaks, and Singapore's personal data protection act 2012. Singapore Journal of Legal Studies. 2012, 391-415. Iegūts no: https://law.nus.edu.sg/sjls/articles/SJLS-Dec-12-391.pdf [sk. 01.04.2018.].

9. Danish Criminal code: Order No. 909 of September 27, 2005, as amended by Act Nos. 1389 and 1400 of December 21, 2005. SCRIBD. Iegūts no: https://www.scribd.com/document/261684665/ Danish-Criminal-Code-07052012 [sk. 31.03.2018.].

10. Datu valsts inspekcijas rekomendācija "Personas datu definīcija”. Datu valsts inspekcija. 2008. Iegūts no: http://www.dvi.gov.lv/lv/wp-content/uploads/jaunumi/publikacijas/Personas_datu_ definicija_rekomendacija.pdf [sk. 31.03.2018.].

11. Decision 029/2008 Mrs G and Aberdeen city council: Deceased person's social work record. Scottish Information Commissioner. Iegūts no: http://www.itspublicknowledge.info/ ApplicationsandDecisions/Decisions/2008/200700962.aspx [sk. 01.04.2018.].

12. Does the Data protection act 1998 cover a deceased person's social work records? ScOPT. 2017. Iegūts no: http://www.scopt.co.uk/archives/3746 [sk. 01.04.2018.].

13. Dzīve pēc nāves internetā jeb - kas notiek ar profilu, cilvēkam aizejot aizsaulē? Jauns.lv. 2014. Iegūts no: http://www.kasjauns.lv/lv/zinas/156964/dzive-pec-naves-interneta-jeb-kas-notiksar-tavu-profilu-kad-tu-nomirsi [sk. 31.03.2018.].

14. Eglīte, E. Personas datu apstrādes tiesiskie aspekti. Jurista Vārds. 40(687), 04.10. 2011, 16-21.

15. Freedom of information (Scotland) Act 2002 (asp 13). UK legislation. Iegūts no: http://www. legislation.gov.uk/asp/2002/13/pdfs/asp_20020013_en.pdf [sk. 01.04.2018.].

16. Guidelines for doctors on disclosing medical records to third parties. Australian Medical association. 2010. Iegūts no: https://ama.com.au/article/guidelines-doctors-disclosing-medicalrecords-third-parties-2010 [sk. 31.03.2018.].

17. Latvijas ārstu ētikas kodekss. Medicina.lv. Iegūts no: http://www.medicina.lv/lat/second4. php?page=zakoni\& $\mathrm{P} 1=4$ [sk. 31.03.2018.].

18. Personal data protection act 2012 (No. 26 of 2012). Singapore Statutes online. 2012. Iegūts no: https://sso.agc.gov.sg/Act/PDPA2012 [sk. 31.03.2018.].

19. Personal information protection and electronic documents act (S. C. 2000, c. 5). Justice laws website. Iegūts no: http://laws-lois.justice.gc.ca/eng/acts/P-8.6/page-2.html\#h-6 [sk. 01.04.2018.].

20. The Data protection act. Act on the protection of privacy as regards the processing of personal data, No. 77/2000 of May 10, 2000. Persónuvernd. 2000. Iegūts no: https://www.personuvernd. is/information-in-english/greinar/nr/438 [sk. 31.03.2018.].

21. The General Medical Council's Guidance on confidentiality. General Medical Council. Iegūts no: http://www.gmc-uk.org/Confidentiality__English_1015.pdf_48902982.pdf [sk. 31.03.2018.].

22. What will happen to my Facebook account if I pass away? Facebook. Iegūts no: https://www. facebook.com/help/103897939701143 [sk. 31.03.2018.]. 